\title{
New pulmonary nodules in a patient with rheumatoid arthritis
}

\author{
Raya Saba, Alaa M Ali, Shawn G Kwatra, Aibek E Mirrakhimov
}

Department of Internal Medicine, Saint Joseph Hospital, Chicago, Illinois, USA

\section{Correspondence to} Dr Aibek E Mirrakhimov, amirrakhimov1@gmail.com

\section{DESCRIPTION}

A 35-year-old male with a history of rheumatoid arthritis and rheumatoid pulmonary nodules and Graves' disease was admitted to the hospital due to new onset fever, worsening dyspnoea and cough. Laboratory workup showed leukocytosis, haematuria, elevated erythrocyte sedimentation rate and cytoplasmic antineutrophil cytoplasmic antibodies. CT of the chest showed an increase in the size and number of lung masses (figure 1) compared to imaging performed 2 years prior, and a new airfluid level mass in the apical area of the right lung (figure 2). Bronchoscopy with bronchoalveolar lavage demonstrated mild interstitial pneumonitis, fibrosis and positive cultures for Streptococcus pneumonia. Transbronchial biopsy showed granulomatous vasculitis. The patient improved after receiving a high dose of methylprednisolone, and levofloxacin. He was discharged home on a maintenance prednisone and levofloxacin.

The presence of pulmonary nodules with cavitation requires a thorough workup to establish a primary diagnosis. ${ }^{1}$ Differential diagnosis includes tuberculosis and other bacterial disease such as nocardiosis, fungal infections such as aspergillosis, granulomatosis with polyangiitis and other autoimmune diseases and malignancy (particularly squamous cell cancer lung cancer). Lung biopsy

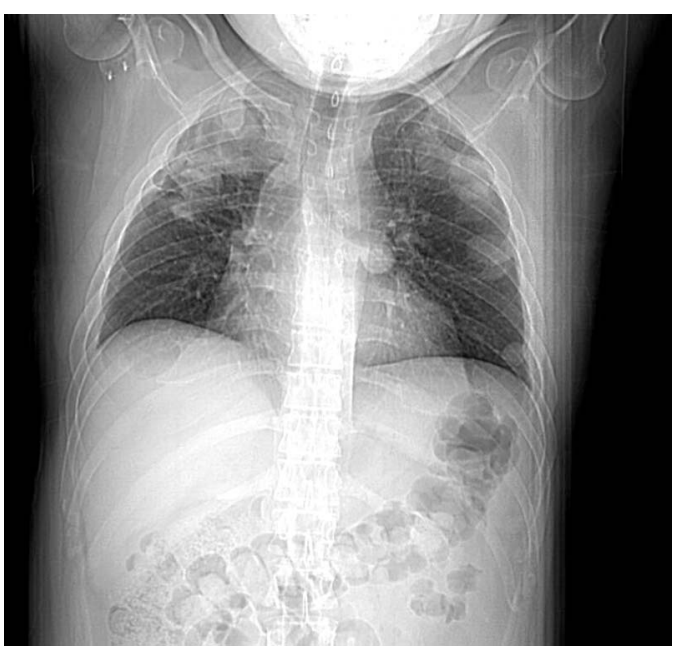

Figure 1 Bilateral pulmonary nodules.

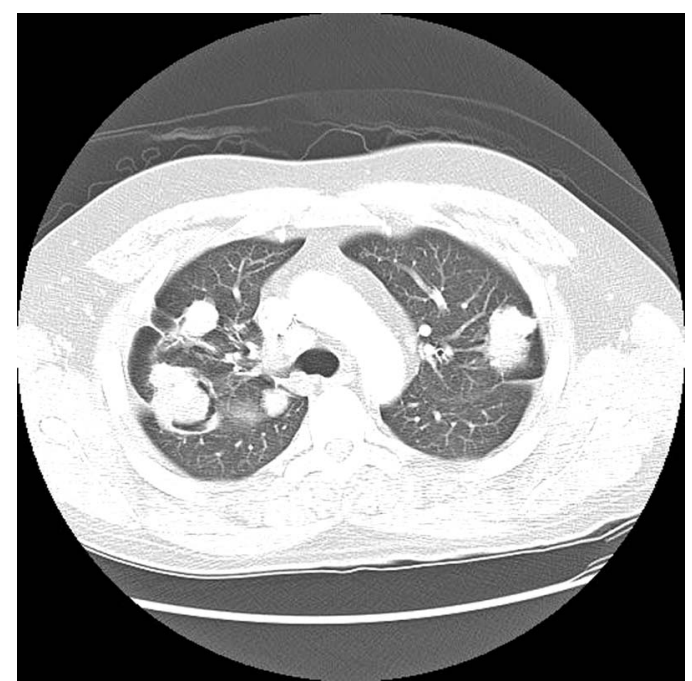

Figure 2 Bilateral pulmonary nodules and air fluid level mass in the right apical area.

may be required to establish a definitive diagnosis. Granulomatosis with polyangiitis is the most common autoimmune disorder presenting with cavitary pulmonary lesions. $^{2}$

\section{Learning points}

- Rheumatoid lung nodules do not usually cavitate and are typically asymptomatic.

- The presence of multiple pulmonary nodules with cavitation should include granulomatosis with polyangiits in the diagnostic workup.

- Lung biopsy may be needed to establish a diagnosis.

Competing interests None.

Patient consent Obtained.

Provenance and peer review Not commissioned; externally peer reviewed.

\section{REFERENCES}

1 Ost DE, Gould MK. Decision making in patients with pulmonary nodules. Am J Respir Crit Care Med 2012;185:363-72.

2 Frankel SK, Schwarz MI. The pulmonary vasculitides. Am J Respir Crit Care Med 2012;186:216-24.
To cite: Saba $\mathrm{R}$, Ali $A M$ Kwatra SG, et al. BMJ Case Rep Published online:

[please include Day Month Year] doi:10.1136/bcr-2012008344 
Copyright 2013 BMJ Publishing Group. All rights reserved. For permission to reuse any of this content visit http://group.bmj.com/group/rights-licensing/permissions.

BMJ Case Report Fellows may re-use this article for personal use and teaching without any further permission.

Become a Fellow of BMJ Case Reports today and you can:

- Submit as many cases as you like

- Enjoy fast sympathetic peer review and rapid publication of accepted articles

- Access all the published articles

- Re-use any of the published material for personal use and teaching without further permission

For information on Institutional Fellowships contact consortiasales@bmjgroup.com

Visit casereports.bmj.com for more articles like this and to become a Fellow 